\title{
Macroeconomic and Demographic Determinants of Residential Property Prices in Malaysia
}

\author{
Ivan D. Trofimov* \\ Nazaria Md. Aris ${ }^{* *}$ \\ Dickson C. D. Xuan
}

Abstract: This paper studies the relationship between residential property prices and macroeconomic and demographic determinants in Malaysia. In the years following the Asian financial crisis, property prices in Malaysia rose substantially, resulting in an affordability crisis and ultimately policy responses to the problem. Using unit root, Johansen-Juselius cointegration, VECM-based Granger causality tests and variance decomposition, and considering quarterly data that covers 2000-2015 period, we established that residential property price growth is principally driven by strong demographic performance and population growth and is backed by the low interest rate environment and rising consumer prices. Household income and level of GDP do not appear to contribute to property price growth. Certain distortions and asymmetries in the Malaysian real estate markets are documented: oversupply in the higher price segment of the market coupled with the lack of affordable housing in the lower price segment; household income growth lagging behind GDP and property price growth, thereby dampening housing demand; growing rental markets in major urban areas as a result of the affordability crisis; and a quality mismatch between buyers' preferences and housing supply.

Keywords: property prices; housing; cointegration

JEL Classification: $\mathrm{C} 22, \mathrm{R} 21, \mathrm{R} 38$

\section{Introduction}

Economic and sociological literature documents the importance of home ownership and residential property for social reproduction and economic development and stability. Residential housing is a 'big ticket' item and a major component of household

\footnotetext{
* Ivan D. Trofimov is at Kolej Yayasan Saad (KYS) Business School Melaka, Malaysia.

*** Nazaria Md. Aris is at University Malaysia Sarawak, Kuching, Malaysia.
} 
expenditure. A major determinant of savings at the micro and macro levels, its affordability is also a major determinant of individual and social well-being, affecting quality of life, life satisfaction, family economics, and durability of social fabric. In addition, the construction sector, real estate, and real estate banking and lending are major parts of the national economy, whilst regulation pertaining to residential real estate is one of the most important government policies. Malfunctioning in the property markets has broad domestic and international implications, compromising financial stability and economic growth, as was evidenced by the global financial crisis of 2007-8. Consideration of residential property prices (as a major component of housing affordability) and their determinants is therefore a salient theoretical, empirical and policy issue in any economy.

Residential housing prices are subject to a plethora of influences related to macroeconomic and demographic conditions, the state of local housing markets, sociological and socio-cultural characteristics of buyers and sellers, and policy factors. In this study, we focus on certain macroeconomic and demographic determinants. The purpose of this study is to examine the effect of selected determinants (population growth, GDP level, household income, level of lending rates, and consumer prices) on the residential housing prices in Malaysia. In contrast to the empirical analysis of the residential property markets in the OECD and selected developing economies (particularly those where housing affordability is the most acute, or where deformations in the residential markets are most visible, e.g. China, Hong Kong, Singapore), the systematic research of housing price determinants in Malaysia will be limited. It will focus on an analysis of supply-side factors, policy instruments that affect property prices, the state of the residential markets in particular localities, and affordability faced by various social groups, or will use data from earlier periods. The novelty of this paper will be its consideration of residential property prices for Malaysia as a whole, and its examination of the influence of macroeconomic and demographic variables on prices in the most recent period.

The essay is organised as follows. Section 2 will provide background information related to the developments taking place in the Malaysian residential property market. Section 3 will provide an overview of theoretical views and empirical analyses pertaining to residential property price determinants. Section 4 will consider data sources, models, and econometric techniques. Section 5 will present empirical findings. Section 6 will offer concluding remarks, provide interpretation of empirical results, discuss the limitations of the research, and outline avenues for future research.

\section{Background}

Residential property markets in Malaysian in the 2000-10s were characterised by conflicting developments and subject to multidirectional forces. Since the early 
2000s, house price increases were experienced in all states of Malaysia, and price growth particularly accelerated in the aftermath of the global financial turmoil of 2008-9 (NAPIC, 2014). For all residential housing categories, the 2014 house price as a multiple of 2000 house price stood at 2.14 for Malaysia as a whole, rising as high as 2.99 and 2.58 in the state of Sabah and in Kuala Lumpur respectively (i.e. prices over 15 year period increased by up to $200 \%$ ). The property market in just one state (Melaka) was characterised as affordable, with median multiple affordability standing at 3.0, whereas markets in all other states and federal territories were classified as moderately, seriously or severely unaffordable (Khazanah Research Institute, 2015).

The underpinning factor of these developments was strong population growth; however, it was also complemented by real estate speculation and government policies that encourage it. Hashim (2010) provides evidence of substantial divergence of the mean from the median house prices, pointing to distortions in housing supply, specifically to proliferation of high-end residential properties and an inadequate supply of affordable and budget housing for working and middle class people. The problem has been aggravated by inconsistent housing policy, with positive incentives for foreign home ownership, exemptions from stamp duty for higher-end property purchases, abolition of the real property gains tax (RPGT) and low base rate have all encouraged real estate speculation.

On the other hand, the importance of affordable housing for Malaysian macro-, urban and social economies has been recognised by the Malaysian government. The rise in property prices out of synchronization with income growth saw policy responses to improve affordability. Firstly, the seventh and eighth Malaysia Plans saw the construction of 1.6 million properties, the majority targeting the housing needs of the low and middle income categories. Secondly, withdrawals from employees' Provident Fund accounts to pay off home loans were permitted from January 2008, in order to reduce the mortgage burden whilst containing property speculation. Thirdly, My First Home Scheme, and the '1Malaysia Housing Program' were launched in 2011 to improve affordability. Fourthly, some previous questionable policies were reversed, such as the re-imposition of PRGT in 2010.

It remains to be seen which tendency will dominate. Hashim (2010) argues that affordability has been improving nationwide since the Asian financial crisis of 19978. On the other hand, a report by the Khazanah Research Institute (2015) identifies an acute affordability problem in most states of Malaysia, driven by the demographic boom and insufficiently addressed by public policy. The latter has tended to pursue a narrow agenda of provision of public housing to low income households, without due consideration of the affordability problems faced by middle income households, particularly in urban areas and large urban agglomerations, ineligible for housing assistance and at the same time unable to purchase property in a free market.

This paper does not focus on the issue of home affordability or on measuring the extent of unaffordability. However, knowledge of the driving forces of property 
prices is instrumental in housing policy formulation and selection of the appropriate policy instruments.

We note the complex demographic setting and ethnic composition of Malaysia that have important implications for Malaysia's urban and social policies and for the real estate market dynamics. Malaysia is a multi-lingual, multi-religious, multi-cultural and multi-ethnic country. The three major ethnic groups are Malays $(65.1 \%$ of the population according to 2000 Census), Chinese (26\%) and Indians (7.7\%). Malays, together with other indigenous ethnic groups in the states of Sarawak and Sabah, are called Bumiputera ("people of the land" in approximate translation). The ethnic differences are not superficial, but have religious (Malays being Muslim, Chinese being Buddhist and Christian, and Indians being Hindu), as well as political dimensions (major political parties are formed on a racial basis - United Malays National Organisation, Malaysian Chinese Association, and Malaysian Indian Congress, collectively forming a coalition that has run Malaysia for most of the post-independence period).

During colonial period, the geographical segregation of three principal ethnic groups was orchestrated by the British colonial administration, with Malays settled in the countryside, Indians directed to the rubber estates, and Chinese to the mining areas. In the post-independence period, the deliberate policies had to be implemented to counter this distortion that constituted an impediment to economic development and nation-building (Yeoh, Hirschman, 1980).

By the time of independence from British colonial rule in 1957, the economic position of the Malays was rather weak: Malays were poorly represented in the corporate and professional circles and in the industrial sector; their ownership of financial assets was also small. According to Gomez and Jomo (1997: 19), "they continued to be concentrated in low-productivity peasant agriculture and the public sector". The situation did not improve in the 1960s, and the riots and political instability in the late 1960s attested to the deteriorating standing of the Malays.

The New Economic Policy (NEP) announced in 1970 intended to foster national unity and nation-building by means of poverty eradication and restructuring of society. The latter measure necessitated economic empowerment of Malays, the ways to achieve this being redistribution of wealth in favour of Malays, creation of Malay middle and business classes, and improvement of social and economic opportunities for this ethnic group.

The assessment of the policy points to mixed outcomes of the NEP. On one hand, the poverty among Malays decreased substantially and the capitalist and middle class expanded (Gomez, Jomo, 1997: 23). The income disparity between three ethnic groups moderated (Lee, 2000). On the other hand, the intra-ethnic inequality among Malays increased (Roslan, 2002). When it comes to social and cultural aspects, Lee (2017) mentions that while Malaysians generally relate well across ethnic lines, and attempt to preserve and enhance ethic peace and harmony, the ethnicity-based affirmative action policies and preferential treatment of Malays (the cornerstone and 
principal objective of NEP) were perceived as unfair by other major ethnic groups (particularly with regard to the access to certain social services, such as education).

When ownership of assets is concerned, the objectives of NEP have not been fully met. The share of Chinese in the ownership of financial assets continues to exceed the share of Malays, albeit the disparity is reduced somewhat due to the rise of Islamic finance and Shariah-compliant financial services that target Malays. Chinese also dominate the real estate market, owning $72.6 \%$ of the business complexes, $69.4 \%$ of industrial premises, $69.3 \%$ of the hotels, and $72.6 \%$ of buildings in total in 2005 (Shafii et al, 2009). Regarding housing policies, Malays have been treated preferentially, with a certain percentage of the total housing development typically reserved for this ethnic group. According to Bujang et al (2008), the preferential allocations to Malays and Bumiputera were rather unsuccessful. Property ownership among Malays and Bumiputera remaining at low levels due to a combination of factors (as also shown in this paper): high selling price (despite the policy arrangement), inability to secure financing, unfavourable type of the property, poor location etc.

\section{Literature Review}

A number of theoretical explanations are advanced to explain the functioning of the residential property markets.

Firstly, inelastic supply and supply side constraints were identified as a driving force. Brueckner (1991) and Dowell (1984) point to reduced supply of land (as an objective factor or a result of growth controls imposed by governments), leading to higher development costs, slack in residential development, and higher and more volatile property prices (Huang \& Tang, 2012). The state of the construction industryincluding the cost of construction materials, wages, technological improvement and innovation-likewise affects the quality and amount of supply.

Secondly, Mankiw and Weil (1989) and Poterba (1991) point to the importance of demographic factors, such as overall population growth, household formation process and population ageing. Population growth in the current period would have positive effects on the demand for housing and house prices in the subsequent periods, i.e. substantial lags are present. Mankiw and Weil argue that in developed economies the demand for residential property will decline when the large population cohort (the Baby Boomer generation) ages and the smaller population cohort (the Baby Bust generation) reaches adulthood, and ages later on, resulting in a significant decline in prices (asset-meltdown hypothesis).

Thirdly, Glaeser (2013) considers the effect of expectations and collective psychology factors, finding that optimistic expectations tend to have greater effect on housing prices and cycles than credit conditions, with a failure to estimate the supply response resulting in over-optimistic views about property and land prices in the future. 
Fourthly, local conditions and the quality of individual property are salient, with implications for prices in specific areas: location, aesthetic and health factors; proximity to protected areas, amenities, and transport infrastructure; proximity to negative externality producers; or other adverse factors, such as electricity infrastructure and high voltage transmission lines (Gregory, Von Winterfeldt, 1996; Poudyal et al., 2009; Debrezion et al., 2006).

Fifthly, the general state of the economy is considered a major determinant of housing prices. Importantly, causality between the two is bidirectional. Macroeconomic conditions affect real estate prices, but real estate prices condition the state of economy; for example, housing booms may have positive effects on household consumption (Quigley, 1999; Girouard \& Blondal, 2001). As noted by Case et al. (2005), the effects of housing prices on real activity tend to be strong, relative to the effects from the stock market, with a sharp decline in house prices having a much bigger impact on output growth than equity price busts.

Sixth, the availability of credit and the interaction between bank lending and demand for property are preponderant. On one hand, as argued by Minsky (1982), Austrian school economics (Thornton, 2009), and more recently by international economic regulators (IMF, 2000; Borio \& Lowe, 2002), the availability of credit affects property demand and (given fixed supply in the short-run) property valuations. The cycles in property prices are thereby credit driven, with credit availability being the function of central banks' prime rates, innovation in lending practices, and the sophistication of housing finance products. On the other hand, property prices affect credit supply and banks' lending capacity and capital position through the valuation and performance of banks' real estate portfolios. Through the wealth effect, property prices alter the value of collateral and the borrowing capacity of households, and thus demand for credit (Bernanke \& Gertler, 1989; Kiyotaki \& Moore, 1997). Empirical evidence tends to support both views. Goodhart (1995) identifies that property prices substantially affected credit growth in selected developed economies, whilst Collyns and Senhadji (2001) reported significant contemporaneous effects of credit on residential property prices in Asian economies.

Seventh, the state of other financial markets and the level of prices in these markets (specifically stock prices) are likely to be determinants of residential prices. On one hand, the rise in stock prices and the appreciation of stock portfolios and associated increase in financial wealth boost investment in real estate (wealth effect), resulting in higher demand for real estate and higher property prices. On the other hand, the opposite causal effects (from property to stock markets) are also likely (Kapopoulos \& Siokis, 2005). As a per credit-price effect, the increase in property prices and respective increase in collateral values for loans spurs lending to firms and households across the economy, stimulating investment and appreciation of financial assets, including stocks.

Finally, the institutional and policy factors affect housing market dynamics, specifically the state and the development of housing finance (market structure in the 
housing finance industry, marketing of housing loan products, refinancing opportunities), and consumer protection regulation, bankruptcy law, and tax incentives (such as the taxation of capital gains and presence of inheritance taxes).

Empirical research has considered a number of developed and developing economies over various periods. The earlier econometric analyses included Nellis and Longbottom (1981), which looked at residential property prices in the UK during the 1960-70s, and Case and Shiller (1990), which investigated house price dynamics in four US cities using quarterly data covering 1970-1986. More recently, the determinants of residential house prices were examined in various individual economies: the UK (Xu \& Tang, 2014), Spain (Esteban \& Altuzarra, 2008; Gimeno \& Martinez-Carrascal, 2010), Hong Kong (Chow \& Shih, 1995; Tse et al., 1999; Leung et al., 2008), Taiwan (Chen et al., 2007; Tsai \& Peng, 2011), Singapore (Lum, 2002), China (Liu \& Shen, 2005; Wang \& Zhang, 2013; Guo \& Wu, 2013), and Iran (Pour et al., 2013). Major comparative studies included Greiber and Setzer (2007), who examined European economies and the US in the periods of 1981-2006 and 19862006, respectively; as well as Hofmann (2003), who considered 20 developed economies in Europe, America, and Asia. Econometric approaches included time-series, cross-sectional and panel data models, including conventional OLS, Engle Granger and Johansen-Juselius cointegration, a variety of unit root tests, Granger causality, Harris and Inder tests, and others. The results were rather contradictory, given the diverse methodologies adopted and diverse variables examined.

Growth of GDP, household income and wealth, and low levels of unemployment were all found to have positive effects on demand, residential house prices, and mortgage repayments in most studies (Nellis \& Longbottom, 1981; Case \& Shiller, 1990; Meen, 2002; Abelson et al., 2005; Liu \& Shen, 2005; Greiber \& Setzer, 2007; Esteban \& Altuzarra, 2008; Tsai \& Peng, 2011; Guo \& Wu, 2013). In Iran, however, the GDP-house price relationship was negative, stemming from the massive oversupply of property and large volume of construction activity during the periods of GDP growth (Pour et al., 2013). The negative income-house price relationship in the UK during 1971-2012 (Xu \& Tang, 2014) was attributed to conflicting consumer choices, with households preferring other types of expenditure and investment (such as child education) to real estate. Non-contemporaneous links between disposable income, credit, construction cost, interest rates, and house prices were also identified, with possible leads and lags, and short- and long-run relationships (Xu \& Tang, 2014).

Land supply constraints, residential development restrictions, and construction costs were principal drivers on the supply side. In the land-scarce markets of Singapore and Hong Kong (Lum, 2002; Leung et al., 2008), as well as in countries with substantial rural-urban migration and fast growth of major urban areas (Guo \& Wu, 2013; Wang \& Zhang, 2013), these factors were the most salient factors in housing shortages and price growth, and were amplified by rapid income growth in the case of China. 
With regard to asset meltdown hypothesis, the empirical studies that followed Mankiw and Weil (1989) contradicted the predictions: prices continued to grow in the 1980-2000s in most developed economies, including those with demographic and homeownership parameters similar to those of the US (Engelhardt \& Poterba, 1991; Pitkin \& Myers, 1994; Piergallini, 2018). We note that a number of studies of developed economies either found no evidence of any significant effect of demographic variables on prices (Peek \& Wilcox, 1991; Fortin \& Leclerc, 2000), or identified these effects as uneven (Levin et al., 2009). Other studies nonetheless maintain that a positive link between population growth and property prices exists (Tse et al., 1999; Liu \& Shen, 2005; Esteban \& Altuzarra, 2008). Overall, the size and direction of demographic effects is uncertain as demographic variables may be confounded with other variables and thus cannot be isolated. In addition, consumption-smoothing over the life cycle, bequest motives, immigration, capital investment abroad, and forward-looking financial markets may play role in offsetting asset meltdown.

Positive effects of inflation on house price growth were experienced in Hong Kong (Chow \& Shih, 1995), China (Liu \& Shen, 2005), as well as in Iran, which experienced periods of hyperinflation (Pour et al., 2013). A two-way relationship between CPI and housing prices is noted, given that housing is included in the CPI calculation (Liu \& Shen, 2005).

The role of monetary and credit variables and financial markets in explaining house price movement was emphasised by Greiber and Setzer (2007) and Goodhart and Hofmann (2008). An increase in money supply and low interest rates were found to be associated with the formation of real estate bubbles and a sustained increase in property prices (Tsai \& Peng, 2011). Strong negative effects of interest rates on prices were experienced in European economies, including the UK, and in Hong Kong, whilst in the US the effects were not significant (Nellis \& Longbottom, 1981; Chow \& Shih, 1995; Sutton, 2002; Greiber \& Setser, 2007; McQuinn \& O’Reilly, 2008). In China, a positive relationship between interest rates and house prices was identified, in contrast to the majority of findings (including those of Guo and $\mathrm{Wu}$, who identified a negative relationship in the Shanghai real estate market). Liu and Shen (2005) attribute this to the regulation of interest rates by the Chinese government. For credit variables, a statistically significant co-movement between credit cycle and house prices was identified in the USA (Greiber \& Setser, 2007). The study of house prices in Spain by Gimeno and Martinez-Carrascal (2010) and Esteban and Altuzarra (2008) likewise established a link between the cost of credit, demand for housing, and the level of household indebtedness. Here, the cost of mortgage financing was found to be negatively related to demand and property prices, and thus the level of debt.

Regarding the interaction between stock and property markets, the majority of empirical studies identified positive correlation between the two, and in many instances long-run relationships and the causality running from stock to real estate prices. The studies include Hoesli and Hamelink, 1997 (Switzerland); Lizieri and 
Satchell, 1997 (UK); Bonnie, 1998 (USA); Abelson et al., 2005 (Australia); Oikarinen, 2010 (Finland), among others. Several reservations were made. Firstly, the stock market could affect real estate through national income (Sutton, 2002); secondly, the effects could be most pronounced in the expensive segment of the property market (Kakes \& Van Den End, 2004); thirdly, in some cases the effects on the stock market could be short-term in nature (Leung et al., 2008), whilst in other cases, the long-run cointegration between the two markets could be present (Takala \& Pere, 1991); and fourthly, contemporaneous relations between the two markets could be absent (Quan \& Titman, 1999).

Chen et al. (2007) argue that the cost of construction, the cost of land, and seasonal factors were the principal determinants of Malaysian residential property prices. Ong (2013) suggests that the quantity and quality of labour force in the construction sector affect the supply of housing. In addition, the Real Property Gains Tax (RPGT) provides incentives for late disposal of properties and affects the purchase decisions of households, including demand for residential properties. The effect of RPGT was negative, though speculation activities and purchasing decisions by high-net-worth individuals were not affected by RPGT.

Tan (2010) considers the influence of interest rates on residential housing prices. Using 2000-2006 quarterly data and pooled random effect model, Tan shows a negative relationship between the level of the base lending rate and the volume of residential properties activities and purchases. Furthermore, a non-significant relationship was found between the volume of residential property transactions and average property prices, specifically for certain local markets and properties of inferior quality (those with unsatisfying locations, for example). Zandi et al. (2015) examines the effects of macroeconomic factors on properties located in urbanised and industrialised areas (Penang state) in the period of 2007-2014. A significant positive relationship with possible lagged effect between the lending rate and price level was identified, despite the majority of previous studies identifying a negative relationship. GDP and gross national income had positive but insignificant effects on prices, whilst inflation had no effect.

In a similar analysis of macroeconomic determinants, Hui (2013), using quarterly data, considers the effects of private consumption, gross investment, stock prices, money supply, interest rates, and bilateral exchange rates on housing prices in Malaysia in the period of 1991-2006. Gross domestic product, investment, and stock price did not substantially affect housing prices. In contrast, exchange rates were found to have negative effect on prices. Money supply was also seen to have a relatively strong effect on housing prices, with Granger causality running in both directions. In contrast, an analysis of macroeconomic variables by Ong (2013) establishes a positive effect of Malaysian GDP and population growth on prices, and an absence of effect by interest rates.

In the broader context of housing affordability, Bujang et al. (2015) consider the dynamics of residential markets in the state of Johor and the associated effects for the 
native ethnic group (Bumiputera). It was found that despite the potential to moderate prices, the policies and products provided by financial institutions did not have strong effects on demand and prices. With ongoing rural-urban migration, demand was rising substantially, effectively precluding Bumiputera from home ownership. Despite loans with more attractive features, the default rates and repayment burden remained high, particularly among lower-income Bumiputera.

An analysis of housing markets and affordability by Hashim (2010) delivers more optimistic findings. Indeed, low affordability of housing was becoming a problem for Malaysia, with incomes lagging behind property prices, and an insufficient supply of low and medium cost properties. However, levels of affordability were not uniform. There was a substantial disparity in housing prices, stemming from income and regional development inequality, with the poorest states (Kelantan) experiencing moderate levels of unaffordability in some years. In addition, a Central Bank intervention resulted in lower interest rates and loan cheapening, whilst solid economic growth led to a gradual rise in household incomes.

Given the contradictory findings, as well as the fact that many of the studies were conducted for specific regions of Malaysia and focused on the effects of policy instruments or supply side factors, the effect of macroeconomic and demographic variables on residential property markets must be re-examined. This study used more recent data, extending to 2015. Acknowledging the local nature of markets and regional disparities, this study focused on the overall dynamics of residential housing in Malaysia and used aggregate housing price index as a dependent variable.

\section{Methodology}

\section{Data Description}

This study aimed to examine the relationship between Malaysian residential property prices (real residential property price index with a base in 2010 , calculated using the hedonic price method) and their determinants, specifically the lending rate, inflation rate, real household income in 2010 constant values, real gross domestic product in 2010 constant values, and the country's population. The study was conducted using quarterly data from the $2000-2015$ period. Residential property was defined to include terraced houses, semi-detached houses, detached houses, and high-rise units. As shown in Table 1, the secondary data were retrieved from the CEIC Global Database, Department of Statistics of Malaysia, Thomson Reuters DataStream, and the database of the National Property Information Centre (NAPIC). 
Table 1: Variables and Corresponding Secondary Data Sources

\begin{tabular}{|l|l|}
\hline Variables & Secondary Data Source \\
\hline House Price Index (HPI) & CEIC Database \\
\hline Base Lending Rate (BLR) & Thomson Reuters DataStream \\
\hline Consumer Price Index (CPI) & CEIC Database \\
\hline Household Income (HI) & Malaysia Department of Statistics \\
\hline $\begin{array}{l}\text { Population Growth (POPGROWTH) } \\
\text { Gross Domestic Product (GDP) }\end{array}$ & $\begin{array}{l}\text { Thomson Reuters DataStream } \\
\text { CEIC Database }\end{array}$ \\
\hline
\end{tabular}

\section{Theoretical Model}

The theoretical model is formulated with residential house prices as the function of the base lending rate, inflation rate, country population, gross domestic product (GDP), and household income:

A linear functional form is adopted:

$$
H P I_{t}=\beta_{0}+\beta_{1} B L R_{t}+\beta_{2} I N F_{t}+\beta_{3} H I_{t}+\beta_{4} P_{t}+\beta_{5} G D P_{t}+\varepsilon_{t}
$$

Where $H P I_{t}$ is house price index in year $t, B L R_{t}$ is the base lending rate in year $t$, $I N F_{t}$ is inflation rate in year $t, H D I_{t}$ is household income in year $t, P_{t}$ is population in year $t, G D P_{t}$ is gross domestic product in year $t, \beta_{0}$ is constant, $\beta_{1}, \beta_{2}, \beta_{3}, \beta_{4}, \beta_{5}$ are partial regression coefficients, and $\varepsilon_{t}$ is an error term. To ensure direct interpretation of coefficients as percentage changes, the model is run on the natural logarithms of the series.

A positive relationship is hypothesised between house prices and population, GDP, household income, and inflation; whilst a negative relationship is likely to be present between house prices and the base lending rate. Thus, $\frac{\partial H P I}{\partial B L R}<0, \frac{\partial H P I}{\partial I N F}>0$, $\frac{\partial H P I}{\partial H D I}>0, \frac{\partial H P I}{\partial P}>0, \frac{\partial H P I}{\partial G D P}>0$.

\section{Econometric Method}

The stationarity and the order of integration of the variables were tested by the Augmented Dickey-Fuller (ADF) and Phillips-Perron (PP) tests.

The Augmented Dickey-Fuller (ADF) test is based on the auxiliary regression as follows:

$$
\Delta Y_{t}=b_{0}+b_{1} t+b_{2} Y_{t-1}+\sum_{i=1}^{k} b_{2+i} \Delta Y_{t-i}+e_{t}
$$


where $y_{t}$ is the logarithm of the respective variable at time t, $y_{t-1}$ is the lag in the first difference, $t$ is trend, $e_{t}$ is the error term adjusted for serial correlation and $k$ is the number of lags chosen to remove serial correlation.

The null and alternative hypotheses are represented as:

$H_{0}: b_{2}=0$ (The series is non-stationary and unit root is present)

$H_{a}: b_{2}<1$ (The series is stationary and unit root is absent)

The Phillips-Perron (PP) unit root test is used to complement the ADF test, which suffers from several shortcomings-including low power in the case of near unit root processes. Being a nonparametric test, it deals with serial correlation and heteroscedasticity of any type by making corrections to t-statistic in the test regressionthereby making it unnecessary to specify lag lengths, as in the ADF test. The test regression is given as:

$$
\Delta y_{t}=\beta^{\prime} D_{t}+\psi y_{t-1}+\varepsilon_{t}
$$

where $D_{t}$ represents deterministic terms, $\varepsilon_{t} \sim I(0)$ and correction for serial correlation and heteroscedasticity is performed on $\varepsilon_{t}$.

The modified statistics are:

$$
\begin{gathered}
Z_{t}=\left(\frac{\hat{\sigma^{2}}}{\hat{\lambda^{2}}}\right)^{1 / 2} \cdot t_{\psi=0}-\frac{1}{2}\left(\frac{\hat{\lambda^{2}-\hat{\sigma^{2}}}}{\hat{\lambda^{2}}}\right) \cdot\left(\frac{T \cdot S E(\psi)}{\hat{\sigma^{2}}}\right) \\
Z_{\psi}=T \hat{\psi}-\frac{1}{2} \frac{T^{2} \cdot \hat{S E(\psi)}}{\hat{\sigma^{2}}}\left(\lambda^{2}-\hat{\sigma^{2}}\right)
\end{gathered}
$$

where $\lambda^{2}$ and $\sigma^{2}$ are consistent estimates of variance.

The two hypotheses set for PP test are similar to those in the ADF test:

$H_{0}: \psi=0$ (The series is non-stationary and unit root is present)

$H_{\mathrm{a}}: \psi<1$ (The series is stationary and unit root is absent)

The Johansen-Juselius cointegration approach is adopted to test the presence of the long run relationship among six variables. The cointegration long-run equation is derived as:

$$
\Delta Z_{t}=\prod Z_{t-1}+\sum_{i=1}^{k-1} \Gamma_{i} \Delta Z_{t-i}+\psi D_{t}+\varepsilon_{t}
$$

Where $Z_{t}$ are variables examined, $\varepsilon_{t}$ is a white noise disturbance with zero mean and finite variance, $D_{t}$ is a vector of deterministic variables, $\Pi$ is the $n \times n$ coefficients matrix, with the rank of $\Pi$ determining the number of cointegrating vectors. 
Two likelihood ratio tests (the maximum eigenvalue and the trace test) are used to identify the number of cointegrating vectors (Johansen, 1988).

The trace test statistic is represented as follows:

$$
\lambda_{\text {trace }}=-T \sum_{i=q+1}^{p} \ln \left(1-\lambda_{i}\right)
$$

Where $\lambda_{\text {trace }}$ is the likelihood ratio statistic, $T$ is the number of observations used in the estimation, $p$ stands for the number of variables, and $q$ is the rank of matrix $\Pi$. The null hypothesis is that the rank of matrix (and hence the number of cointegrating relationships) is $q$, in effect: $H_{0}: \operatorname{rank}(\Pi)=q$. The alternative hypothesis is that the rank of the matrix is higher than $q$ but lower or equal to $n$, which is defined as the maximum possible number of cointegrating relations, i.e. $H_{\mathrm{a}}: q<\operatorname{rank}(\Pi) \leq n$. The trace test proceeds sequentially until the first non-rejection of the null.

The maximum eigenvalue test statistic is shown as:

$$
\lambda_{\max }=-T \ln \left(1-\lambda_{q+1}\right)
$$

The null hypothesis is that there are no cointegrating relations and the rank of matrix is zero, in effect: $H_{0}: \operatorname{rank}(\Pi)=0$. The alternative hypothesis is that there is a single cointegrating relation, in effect: $H_{0}: \operatorname{rank}(\Pi)=q=1$. Thus, the test considers sequentially whether the largest eigenvalue is zero (under null hypothesis) or the next largest eigenvalue is zero (under the alternative hypothesis).

Given that the results of the Johansen-Juselius tests may suffer from size bias (over-rejection of the null hypothesis of no cointegration), a correction to trace and maximum eigenvalue statistics may be needed in small samples. We adopt the correction factor derived by Reinsel and Ahn (1992) as $(T-p k) / T$, where $T$ is the sample size, $p$ is the total number of variables, and $k$ is the lag length.

Following determination of the number of cointegrating vectors and of the fact that variables co-move in the long-run, Granger causality is examined in order to establish the direction of influence among the variables in the short- and long-run.

Granger causality is tested within the VECM framework if variables in levels are nonstationary and there exists a cointegrating relationship among them. In contrast, in the absence of cointegration, the VAR model is run on the differenced variables and causality is established in the VAR context. VECM (as a restricted VAR for nonstationary variables) restricts the long-run dynamics, whilst allowing for short-run adjustments towards long-run equilibrium. For correctly specified VECM, the respective value of the error correction term is negative and belongs to the $(0 ;-1)$ range, thereby allowing such adjustment. In VECM, two sources of causality are identified: long-run, captured by error-correction term (ECT), and short-run, captured by lagged explanatory variables. 
The VECM in a two-variable case augments bivariate VAR and is represented as follows:

$$
\begin{gathered}
\Delta Y_{t}=\alpha+\gamma e_{t-1}+\beta_{11} \Delta Y_{t-1}+\ldots+\beta_{1 k} \Delta Y_{t-k}+\theta_{11} \Delta X_{t-1}+\ldots+\theta_{1 k} \Delta X_{t-k}+\varepsilon_{1 t} \\
\Delta X_{t}=\beta+\lambda v_{t-1}+\beta_{21} \Delta X_{t-1}+\ldots+\beta_{2 k} \Delta X_{t-k}+\theta_{21} \Delta Y_{t-1}+\ldots+\theta_{2 k} \Delta Y_{t-k}+\varepsilon_{2 t}
\end{gathered}
$$

where $e_{t-1}$ and $v_{t-1}$ are the lagged value of ECT, and $\varepsilon_{1 t}$ and $\varepsilon_{2 t}$ are white noise disturbances.

For a five-variable case, and residential property prices as the dependent variable, VECM is re-written as:

$$
\begin{aligned}
& \Delta H P I_{t}=\alpha+\sum_{i=1}^{k} \theta_{1 t} \Delta H P I_{t-1}+\sum_{i=1}^{k} \theta_{2 i} \Delta B L R_{t-1}+\sum_{i=1}^{k} \theta_{3 t} \Delta I N F_{t-1}+\sum_{i=1}^{k} \theta_{4 t} \Delta H I_{t-1}+\sum_{i=1}^{k} \theta_{5 t} \Delta P_{t-1}+ \\
& +\sum_{i=1}^{k} \theta_{6 t} \Delta G D P_{t-1}+\lambda\left(H P I_{t-1}-\beta_{1} B L R_{t-1}-\beta_{2} I N F_{t-1}-\beta_{3} H I_{t-1}-\beta_{4} P_{t-1}-\beta_{5} G D P_{t-1}-\beta\right)+\varepsilon_{t}
\end{aligned}
$$

Where $\lambda$ is the ECT coefficient and thereby indicates the adjustment to long-run equilibrium, $\left(H P I_{t-1}-\beta_{1} B L R_{t-1}-\beta_{2} I N F_{t-1}-\beta_{3} H I_{t-1}-\beta_{4} P_{t-1}-\beta_{5} G D P_{t-1}-\beta\right)$ is the error-correction term, $\varepsilon_{t}$ is a white noise disturbance, $\alpha$ and $\beta$ are constants, and $\Theta_{1 t} \ldots \Theta_{6 t}$ are coefficients of the variables that indicate a short-run relationship.

The null hypothesis for the VECM based Granger causality test is that variables do not cause one another; in effect: in Equation (9) $X_{t}$ does not Granger-cause $Y_{t}$ and in Equation (10) $Y_{t}$ does not Granger-cause $X_{t}$. Thus, $H_{0}: \theta_{11}=\ldots=\theta_{1 k}=0$ or $H_{0}: \theta_{21}=\ldots=\theta_{2 k}=0$. Respectively, short-run Granger causality in Equation (9) is established if coefficients $\Theta_{21} \ldots \Theta_{2 k}$ are jointly significant. Likewise, $\Theta_{21} \ldots \Theta_{2 k}$ are jointly significant in Equation (10). The presence of significant coefficients in both equations would point to bilateral causality. The statistical significance of $e_{t-1}$ and $v_{t-1}$ would indicate long-run Granger causality.

Forecast variance decomposition is performed to show the breakdown of the forecast error variance for a variable at different horizons, or to identify how shocks to specific variables pass through the system. Specifically, the method compares the relative importance of population growth, GDP, inflation, interest rates, and household income in explaining property prices, and-given that forecast error variances evolve over time-establishes how these relative contributions change.

\section{Empirical Results}

As a first step, unit root tests were conducted. The ADF unit root test results (Table 2) show that all variables are non-stationary in levels (under intercept and intercept plus 
trend specifications). For instance, the t-statistics for the natural logarithm of the house price index is 3.321 (in levels and with intercept), which is smaller than the critical value of -3.538 at a $1 \%$ level of significance. Therefore, the null hypothesis is not rejected and it is concluded that the natural logarithm of the house price index contains a unit root.

$\mathrm{ADF}$ unit root test results indicate that all of the variables in question are stationary in first differences (under both specifications mentioned above), indicating the absence of a unit root. For instance, the t-statistics for the natural logarithm of the consumer price index is -6.852 in the first difference (specification with intercept), exceeding the critical value of -3.542 at a $1 \%$ level of significance.

Table 2: Result of Augmented Dickey Fuller (ADF) Unit Root Test

\begin{tabular}{|l|c|c|c|c|c|c|c|c|}
\hline \multicolumn{1}{|c|}{ Variables } & \multicolumn{3}{c|}{ Level } & \multicolumn{4}{c|}{ 1st Difference } \\
\hline & Intercept & & Trend and Intercept & & Intercept & & \multicolumn{2}{c|}{ Trend and Intercept } \\
\hline LHPI & 3.321 & 0 & -0.526 & 0 & $-3.764 * * *$ & 1 & $-7.711^{* * *}$ & 0 \\
\hline LBLR & -1.886 & 0 & -1.995 & 0 & $-5.876^{* * *}$ & 0 & $-5.892^{* * *}$ & 0 \\
\hline LCPI & 0.611 & 0 & -2.868 & 0 & $-6.852^{* * *}$ & 0 & $-6.853^{* * *}$ & 0 \\
\hline POPGROWTH & -1.923 & 0 & -2.939 & 0 & $-9.615^{* * *}$ & 0 & $-9.914 * * *$ & 0 \\
\hline LINCOME & 0.871 & 0 & -1.864 & 0 & $-10.129 * * *$ & 0 & $-10.413^{* * *}$ & 0 \\
\hline LGDP & -0.195 & 0 & -1.265 & 0 & $-9.827 * * *$ & 1 & $-9.738^{* * *}$ & 1 \\
\hline
\end{tabular}

Note: LHPI is the natural logarithm of house price index, LBLR is the natural logarithm of base lending rate, LCPI is the natural logarithm of consumer price index, POPGROWTH is population growth, LINCOME is natural logarithm of household income, LGDP is the natural logarithm of gross domestic product. (*), (**) and (***) indicate $10 \%$, $5 \%$ and $1 \%$ levels of significance, respectively. Lags are selected based on Schwarz Information Criterion (SIC). Figures in parentheses are lag lengths.

The PP test yields similar results (Table 3). All variables are non-stationary in levels under both intercept and trend plus intercept specifications. The PP test also shows that all variables are stationary in first differences. Given that all variables are I(1), or non-stationary in levels but stationary in first difference, the use of the Johansen-Juselius methodology is justified.

Table 3: Result of Philips-Perron (PP) Unit Root Test

\begin{tabular}{|l|c|c|c|c|c|c|c|c|}
\hline \multicolumn{1}{|c|}{ Variables } & \multicolumn{3}{|c|}{ Level } & \multicolumn{4}{c|}{ 1st Difference } \\
\hline & Intercept & & Trend and Intercept & & Intercept & & Trend and Intercept & \\
\hline LHPI & 3.281 & 2 & -0.528 & 2 & $-6.535^{* * *}$ & 4 & $-7.729 * * *$ & 3 \\
\hline LBLR & -2.346 & 3 & -2.396 & 3 & $-5.876^{* * *}$ & 1 & $-5.894 * * *$ & 1 \\
\hline LCPI & 0.932 & 7 & -2.947 & 3 & $-6.996^{* * *}$ & 8 & $-7.052^{* * *}$ & 8 \\
\hline POPGROWTH & -2.385 & 2 & -2.760 & 2 & $-10.138^{* * *}$ & 2 & $-10.891^{* * *}$ & 2 \\
\hline LINCOME & 3.802 & 3 & -1.020 & 3 & $-13.240^{* * *}$ & 3 & $-18.558^{* * *}$ & 3 \\
\hline LGDP & -0.258 & 3 & -2.158 & 3 & $-3.305^{* *}$ & 3 & $-3.289 *$ & 3 \\
\hline
\end{tabular}

Note: As per Table 1. 
Table 4 (below) shows the results obtained from the Johansen-Juselius cointegration test. The number of lags of the first differenced terms to be used in the test is set to the minimum: $\mathrm{k}=2$. Given that series have non-zero mean and likely contain stochastic trends, the test is run with intercept (but not trend), which belongs only in the cointegrating relation. The maximum number of relationships is set to $r=5$, and the test is run sequentially until the first non-rejection of the null hypothesis.

Table 4: Result of Johansen-Juselius Cointegration Test

\begin{tabular}{|c|c|c|c|c|c|c|c|}
\hline & & & Trace & & \multicolumn{3}{|c|}{ Max Eigenvalue } \\
\hline Null & Alternative & Unadjusted & Adjusted & $99 \%$ C.V. & Unadjusted & Adjusted & $99 \%$ C.V. \\
\hline $\mathrm{k}=3, \mathrm{r}=1$ & & & & & & & \\
\hline $\mathrm{r}=0$ & $\mathrm{r}=1$ & 164.934 & $118.546^{*}$ & 104.962 & 68.04 & $48.903^{*}$ & 45.869 \\
\hline $\mathrm{r} \leq 1$ & $\mathrm{r}=2$ & 96.895 & 69.643 & 77.819 & 43.759 & 31.452 & 39.37 \\
\hline $\mathrm{r} \leq 2$ & $\mathrm{r}=3$ & 53.136 & 38.191 & 54.682 & 26.815 & 19.273 & 32.715 \\
\hline $\mathrm{r} \leq 3$ & $\mathrm{r}=4$ & 26.321 & 18.982 & 35.458 & 21.065 & 15.14 & 25.861 \\
\hline $\mathrm{r} \leq 4$ & $\mathrm{r}=5$ & 5.256 & 3.778 & 19.937 & 5.245 & 3.77 & 18.52 \\
\hline $\mathrm{r} \leq 5$ & $\mathrm{r}=6$ & 0.011 & 0.008 & 6.635 & 0.011 & 0.079 & 6.635 \\
\hline
\end{tabular}

Note: The lag length is $\mathrm{k}$ and $\mathrm{r}$ is the number of cointegrating vectors under trace and maximum eigenvalue tests. $(*)$ represents rejection of the hypothesis at $1 \%$ level of significance.

The adjusted test statistics for the trace test is 118.546 , exceeding the critical value of 104.962 at a $1 \%$ level of significance. Thus, the null hypothesis of no cointegration $(r=0)$ is rejected for LHPI, LBLR, LCPI, POPGROWTH, LINCOME, and LGDP. The maximum eigenvalue test statistic is 48.903 , exceeding the critical value of 45.869 at $1 \%$ level of significance. Since the null hypotheses for the maximum eigenvalue and the trace tests are similar, the null hypothesis is also rejected.

Just one cointegrating vector with a $1 \%$ level of significance is identified, suggesting that there is a single long-run relationship between the variables (LHPI, LBLR, LCPI, POPGROWTH, LINCOME, and LGDP). The normalised cointegrating vector is represented as follows (with t-statistics indicated in parentheses):

$$
\begin{array}{cccc}
L H P I=-2.290+0.999 P O P G R O W T H & -0.854 L G D P-0.294 L I N C O M E+2.153 L C P I-0.160 B L R \\
(14.071) & (-5.641) & (-8.242)
\end{array}
$$

The coefficient of the population growth variable has a positive sign, indicating that when there is a $1 \%$ increase in population growth, there is a $0.999 \%$ increase in residential house prices. With regard to the GDP variable, the respective coefficient has a negative sign, suggesting that a $1 \%$ increase in GDP brings a $0.854 \%$ decrease in the level of residential property prices. A similar negative relationship is observed between the natural logarithm of household income and level of prices (a 1\% increase in the former resulting in a $0.294 \%$ decrease in the latter). Changes in the consumer 
price index have a positive association with changes in residential property price levels, with a $1 \%$ increase in the consumer price index bringing an increase of $2.153 \%$ in the level of prices. This is in line with the majority of studies, which point to the positive contribution of consumer goods inflation to the residential property inflation.

Finally, there is a negative relationship between the base lending rate and level of residential property prices, with a $0.16 \%$ decrease in the house price index per $1 \%$ increase in lending rate. A possible explanation for the phenomena is that a decrease in the base lending rate contributes to a cheapening of mortgages and home loans, thereby encouraging residential property purchases, in turn resulting in higher demand for homes and higher prices. (In the context of the Malaysian property market developments in recent years, a negative relationship between base lending rate and prices would likely reflect the spur in speculative activities.)

A positive relationship between population growth and property price change is not surprising, given the status of Malaysia as a country with rapid (albeit decelerating) population growth (Department of Statistics, 2015), and the effect that population growth has on the demand for residential property. The results are therefore consistent with Liu and Shen (2005), Ong (2013), Guo and Wu (2013), and Tse et al. (1999).

The negative long-run relationship between GDP and residential property prices is unexpected. A theoretical explanation is proposed by Pour et al. (2013): that consistently high economic growth may over-stimulate residential construction, resulting in excessive residential construction and a decrease in property prices. Indeed, as documented by Bujang et al. (2010), the property overhang in Peninsular Malaysia in 2005 has been substantial, with the number of unsold properties totalling 755,000 units. A similar property oversupply has been observed by Bank Negara Malaysia in recent years, particularly in the higher price segment (Ling et al., 2017). This development is coupled with undersupply of housing in other segments, resulting in decreased affordability and higher property prices faced by lower- and middle-income households.

The negative relationship between household income and property prices is supported by the findings by $\mathrm{Xu}$ and Tang (2014) and Bujang (2010). The consumption preference towards renting (rather than ownership of property), or towards particular types of property and other consumption items (vehicles, for example) may dampen demand for property, despite growing income levels. As noted by Bujang (2010), housing development decisions by local and state authorities tend to be based on population trends, without due study of consumer preferences. For instance, in Johor Bahru, a survey of households identified a preference for new housing schemes with better design and higher quality, implying the persistence of a property overhang in certain categories. The preference for higher quality lifestyle housing was confirmed by Sarip and Lee (2015).

An additional factor behind the negative income-price relationship, which was likely to offset higher property prices (due to population growth and a lack of afford- 
able housing construction), is a persistent gap between population and GDP growth on one hand and income and wage growth on the other, resulting in low labour share of GDP. In the property market, this tendency leads to lower demand-particularly among lower-income or newly formed households-and exercises a downward pressure on prices, despite moderate income growth.

Empirical evidence appears to provide some support (albeit not unequivocal) to the GDP-income gap hypothesis. On one hand, the change in household income in recent years has been positive and the labour share of income has increased ( $\mathrm{Ng}, 2017)$. On the other hand, some of the developments in the labour market were adverse. Despite the Economic Transformation Programme (ETP) launched in September 2010, and allied initiatives, the majority of jobs that have been created since then have been in the low and mid skill and salary segments, whilst the unemployment rate for the 20-24 age group has remained high (Lim, 2016). Similar tendencies are identified by Rasiah et al. (2015): since the late 1990s, the labour market in Malaysia has been characterised by slow manufacturing wage growth, increased presence of foreign workers, outsourcing and contracting, and a low degree of unionisation.

The Johansen-Juselius cointegration test determined that there is a single cointegrating vector, and unit root tests determined that variables (when represented in levels) were non-stationary. Thus, the use of vector error correction model (VECM) and subsequent testing for causality in VECM context are justified.

The vector error correction model (VECM) Granger causality test results are shown in Table 5 below.

There exists unidirectional short-run Granger causality-significant at the $1 \%$ level-from population growth to household income, from GDP to consumer price index, from the base lending rate to consumer price index, and from personal income to the house price index. In addition, at a 5\% level of significance, the unidirectional short-run causality runs from population growth to GDP, and from GDP to the base lending rate. At a $10 \%$ level of significance, house price index Granger causes household income, population growth Granger causes house price index, and household income Granger causes population growth. Overall, two bidirectional causation cases are identified: house price index and income, and population growth and income. In the long-run, Granger causality runs from house price index to population growth.

Given that this study focused specifically on the determinants of residential property prices, the evidence from Granger causality tests suggests that short-run causality runs from demographics and broader economic factors (growth of population and income) to residential property prices, but not from monetary variables, such as interest rates (notwithstanding the fact that the long-run equilibrium relationship indicates cointegration between lending rates and consumer price index on one side and house prices on the other). This result is in line with the findings of Tse et al. (1999), Liu and Shen (2005), and Esteban and Altuzarra (2008) in the context of OECD and selected developing economies, and Ong (2013) in the Malaysian context. 
Table 5: VECM Granger causality

\begin{tabular}{|c|c|c|c|c|c|c|c|c|}
\hline Variables & $\Delta \mathrm{LHPI}$ & $\begin{array}{c}\Delta \mathrm{POP} \\
\text { GROWTH }\end{array}$ & $\Delta \mathrm{LGDP}$ & $\Delta \mathrm{LCPI}$ & $\Delta \mathrm{LBLR}$ & $\triangle \mathrm{LINCOME}$ & \multicolumn{2}{|c|}{ ECT } \\
\hline & \multicolumn{6}{|c|}{$\chi^{2}$-Statistics } & Coefficients & t-stat \\
\hline \multirow[t]{2}{*}{$\Delta$ LHPI } & \multirow{2}{*}{-} & 7.745 & 0.182 & 0.583 & 2.767 & 21.62 & \multirow{2}{*}{-0.032} & \multirow{2}{*}{-1.456} \\
\hline & & $(0.052)$ & (0.981) & $(0.900)$ & $(0.429)$ & $(0.000)^{* *}$ & & \\
\hline \multirow[t]{2}{*}{$\Delta$ POPGROWTH } & 2.417 & \multirow{2}{*}{-} & 0.209 & 1.149 & 4.929 & 6.846 & \multirow{2}{*}{-0.273} & \multirow{2}{*}{-12.241} \\
\hline & $(0.491)$ & & $(0.976)$ & $(0.765)$ & $(0.177)$ & $(0.077)$ & & \\
\hline \multirow[t]{2}{*}{$\Delta \mathrm{LGDP}$} & 1.641 & 9.486 & \multirow{2}{*}{ - } & 2.437 & 5.427 & 1.07 & \multirow{2}{*}{-0.003} & \multirow{2}{*}{-1.648} \\
\hline & $(0.650)$ & $(0.024)^{* *}$ & & $(0.487)$ & $(0.143)$ & $(0.784)$ & & \\
\hline \multirow[t]{2}{*}{$\Delta \mathrm{LCPI}$} & 3.357 & 0.689 & 17.668 & \multirow{2}{*}{ - } & 21.862 & 0.821 & \multirow{2}{*}{-0.016} & \multirow{2}{*}{-0.960} \\
\hline & $(0.340)$ & $(0.196)$ & $(0.001)^{* *}$ & & $(0.000)^{* *}$ & $(0.844)$ & & \\
\hline \multirow[t]{2}{*}{$\Delta \mathrm{LBLR}$} & 0.926 & 2.169 & 8.508 & 1.311 & \multirow{2}{*}{ - } & 1.556 & \multirow{2}{*}{-0.006} & \multirow{2}{*}{-0.120} \\
\hline & $(0.819)$ & $(0.538)$ & $(0.037)^{* *}$ & $(0.727)$ & & $(0.669)$ & & \\
\hline \multirow[t]{2}{*}{$\triangle \mathrm{LINCOME}$} & 7.091 & 39.545 & 0.065 & 1.39 & 5.091 & \multirow{2}{*}{-} & \multirow{2}{*}{0.134} & \multirow{2}{*}{4.642} \\
\hline & $(0.069)$ & $(0.000)^{* *}$ & $(0.996)$ & $(0.708)$ & $(0.165)$ & & & \\
\hline
\end{tabular}

Note: The Block Exogeneity Wald Test is employed to test for causality. (*), (**) and (***) indicate rejection of the null hypothesis and statistical significance of $1 \%, 5 \%$ and $10 \%$, respectively. The lag order of VECM was set to 3 . T-statistics are indicated in parentheses.

Another important implication of the Granger causality test findings is that residential property prices are sensitive to changes in household income, but not to GDP growth, thereby pointing to the importance of distributional and affordability issues and policy incentives, rather than economic growth per se. The long-run causality from property prices to population growth may appear spurious; however, as argued by Mulder (2006), the effect that house prices have on household formation and marriage, as well as on decisions to have children, is significant in many instances. Whether these effects are present in Malaysia (and whether economic factors have primacy over cultural, religious and other non-economic factors, particularly among Muslim Malays) is a topic that requires separate analysis. We also note that the Granger causality results presented above indicate temporal ordering variables and 'firstness' of any particular variable, rather than causality in a strict economic and philosophical sense. Defined in terms of predictability and forecasting power, Granger causality may, however, provide some indication of the true economic influence (Geweke, 1984; Dawson, 2003).

Results of the forecast variance decomposition for endogenous and exogenous variables are presented in Table 6 . The respective forecast horizon is set at ten quarters (though only the values for the second, fifth, seventh, and tenth quarters are shown), and factorisation using Cholesky decomposition is performed. The standard error column represents the forecast error for respective variables at different horizons.

It can be seen that own shocks to property prices are salient both in the short- and long-run, contributing to $95 \%$ of property price forecast error variance after two quar- 
ters and $94 \%$ after ten quarters. The relative contribution of the consumer price index to property price forecast error variance rises to $4 \%$ after ten quarters, whilst other variables are insignificant in explaining changes in property prices in the short- and long-run. Property price index is therefore the most exogenous variable in the system. Similar patterns are observed in the case of variance decomposition for consumer price index and the base lending rate, where own shocks contributed to $71 \%$ and $84 \%$ of variance in the respective variable after ten quarters. In contrast, the own shocks to GDP, population growth, and household income are of a smaller magnitude, contributing to $42 \%, 43 \%$, and $4 \%$ of variance in the variables after ten quarters. Therefore, GDP, population growth, and household income are the most endogenous variables.

Table 6: Forecast variance decomposition results

\begin{tabular}{|c|c|c|c|c|c|c|c|}
\hline \multicolumn{8}{|c|}{ Variance decomposition of HPI } \\
\hline Period & S.E. & LHPI & LCPI & LBLR & LGDP & POP GROWTH & LINCOME \\
\hline 2 & 0.016 & 94.977 & 2.628 & 0.009 & 0.000 & 1.903 & 0.483 \\
\hline 5 & 0.036 & 94.017 & 5.125 & 0.214 & 0.093 & 0.388 & 0.163 \\
\hline 7 & 0.049 & 93.699 & 5.149 & 0.254 & 0.443 & 0.274 & 0.181 \\
\hline 10 & 0.065 & 93.660 & 4.018 & 0.160 & 1.857 & 0.164 & 0.141 \\
\hline \multicolumn{8}{|c|}{ Variance decomposition of CPI } \\
\hline 2 & 0.011 & 0.217 & 98.003 & 1.017 & 0.012 & 0.677 & 0.073 \\
\hline 5 & 0.014 & 0.517 & 88.047 & 7.231 & 0.239 & 3.609 & 0.357 \\
\hline 7 & 0.016 & 0.481 & 82.080 & 11.911 & 1.791 & 3.373 & 0.365 \\
\hline 10 & 0.018 & 0.523 & 70.798 & 19.633 & 5.509 & 3.179 & 0.358 \\
\hline \multicolumn{8}{|c|}{ Variance decomposition of BLR } \\
\hline 2 & 0.037 & 6.076 & 13.399 & 76.793 & 0.322 & 3.145 & 0.266 \\
\hline 5 & 0.074 & 4.585 & 7.625 & 80.274 & 2.142 & 4.972 & 0.403 \\
\hline 7 & 0.093 & 4.077 & 8.274 & 81.600 & 1.737 & 3.975 & 0.338 \\
\hline 10 & 0.112 & 3.181 & 7.374 & 83.749 & 1.587 & 3.793 & 0.316 \\
\hline \multicolumn{8}{|c|}{ Variance decomposition of LGDP } \\
\hline 2 & 0.003 & 2.553 & 3.303 & 4.183 & 89.959 & 0.003 & 0.000 \\
\hline 5 & 0.017 & 2.153 & 23.312 & 8.979 & 65.468 & 0.088 & 0.000 \\
\hline 7 & 0.028 & 1.721 & 33.891 & 12.518 & 51.691 & 0.176 & 0.003 \\
\hline 10 & 0.039 & 1.151 & 41.096 & 15.938 & 41.570 & 0.238 & 0.007 \\
\hline \multicolumn{8}{|c|}{ Variance decomposition of POPGROWTH } \\
\hline 2 & 0.013 & 4.233 & 4.703 & 0.699 & 0.088 & 87.798 & 2.479 \\
\hline 5 & 0.019 & 15.190 & 14.382 & 5.347 & 1.310 & 60.614 & 3.156 \\
\hline 7 & 0.022 & 12.836 & 22.599 & 7.023 & 1.140 & 53.119 & 3.283 \\
\hline 10 & 0.026 & 10.072 & 35.349 & 7.575 & 1.219 & 42.536 & 3.249 \\
\hline \multicolumn{8}{|c|}{ Variance decomposition of LINCOME } \\
\hline 2 & 0.018 & 31.586 & 0.124 & 0.721 & 0.082 & 54.368 & 13.119 \\
\hline 5 & 0.033 & 61.919 & 0.125 & 1.032 & 1.200 & 28.201 & 7.523 \\
\hline 7 & 0.043 & 70.680 & 0.287 & 0.612 & 2.245 & 21.238 & 4.938 \\
\hline 10 & 0.058 & 75.603 & 0.244 & 0.427 & 3.428 & 16.333 & 3.965 \\
\hline
\end{tabular}




\section{Conclusion}

This study aimed to explain the macroeconomic and demographic determinants of Malaysian residential property prices during the period of 2001-2015. Quarterly data was used and time-series econometric methods (unit root tests, Johansen-Juselius cointegration, Granger causality based on VECM, and variance decomposition) were employed.

It was found that population had a significant and positive effect on the demand for residential properties and, consequently, on the price of residential properties in Malaysia. The results obtained are in line with those of the majority of previous studies (Liu \& Shen, 2005; Ong, 2013; Guo \& Wu, 2013; Tse, Ho \& Ganesan, 1999). Gross domestic product was negatively and significantly related to the prices of residential properties in Malaysia. The result obtained is in line with that of Pour et al. (2013): economic growth gives rise to housing supply expansion, which depresses prices. Given that property prices continued to grow over a sustained period, it is unlikely that this effect played a dominant role-except in the high-end segment of the property market, where oversupply was evident. The existence of a significant and negative relationship between household income and housing prices is supported by the findings of Xu and Tang (2014), Bujang (2010), and Rasiah et al. (2015): more sophisticated consumer preferences, which are not matched by the current housing supply, coupled with a growing trend for renting rather than owning property (particularly in overpriced locations), and income growth not catching up with property prices, were likely to exert a downward pressure on the demand side, thus lowering prices.

The study also identified a negative and significant relationship between base lending rate and prices for residential properties, in line with economic theory (high financing costs discouraging property purchases) and empirical research by Tan (2010), Nellis and Longbottom (1981), and Guo and Wu (2013). Finally, a significant and positive relationship between the consumer price index and residential property prices (the latter being a constituent part of the former) was observed, in line with previous findings by Liu and Shen (2005) and Pour et al. (2013).

Several policy measures (some of which have already been accepted by regulators) follow from this paper's findings. Firstly, given the strong dependence of prices on demographic factors, ongoing supply expansion is needed, based on the identification of consumer preferences for quality housing and the particular areas where the affordability crisis is the most acute. This requires further modernisation and growth of the construction industry in order to cope with growing demand, as well as adjustment of construction standards and protocols. Secondly, other supply-side measures may be needed, including greater allocation of land for residential development, in order to decrease the high cost of land for residential housing: a departure from previous land policies that have envisaged substantial set-asides of land for public 
areas and commons. Of particular importance are measures to stimulate residential construction in the low-price range.

Thirdly, given the negative relationship between property prices and incomes, further social policy and economic restructuring measures may be required to address significant income inequality and wages lagging behind property price growth. On a broader level, as proposed by the National Economic Advisory Council (2010), a move towards a new economic model based on labour force skill upgrading, more vigorous productivity growth, and specialization in high value added production may be necessary. Finally, given that low interest rates in recent years have fuelled property speculation and brought in higher prices across the board, stricter regulation of property financing is justified; for example, measures to restrict lending to buyers with multiple property portfolios, and assessment of total debt obligations prior to lending.

A future analysis of the property market drivers in Malaysia could consider additional determinants, such as the state of the rental market, the level of wealth (as measured by the aggregate value of the stock market), the influence of exchange rates on property investment decisions by foreign buyers, the elasticity of the housing supply, and the state of the construction industry. In addition, given the high level of income stratification in Malaysia and the segmented nature of the property market (with property oversupply in the top-end segment being paralleled by under-supply and rising prices in the low end), future research could consider specific sections of the market and the purchasing decisions of particular groups of households, such as working adults or newly formed households.

\section{REFERENCES}

Abelson, P., Joyeux, R., Milunovich, G. \& Chung, D. (2005). Explaining house prices in Australia. Economic Record, 81(s1), 96-103.

Bernanke, B. \& Gertler, M. (1989). Agency costs, collateral and business fluctuations. American Economic Review, 79(1), 14-31.

Bonnie, B. J. (1998). The dynamic impact of macroeconomic aggregates on housing prices and stock of houses: a national and regional analysis. Journal of Real Estate Finance and Economics, 17(2), 179-197.

Borio, C. \& Lowe, P. (2002). Asset prices, financial and monetary stability: exploring the nexus. Basel, Bank of International Settlements Working Paper No. 114.

Brueckner, J. K. (1990). Growth controls and land values. Land Economics, 66(3), 237-48.

Bujang, A., Abu Zarin, H. \& Agus. M. R. (2008). Urban housing ownership: the problems faced by the Bumiputera in the district of Johor Bahru, Johor, Malaysia. International Real Estate Research Symposium (IRERS) 2008, 28-30 April.

Bujang, A., Jiram, W. A., Zarin, H. A. \& Jaafar, M. N. (2015). Factors affecting the housing financing of Bumiputera in Iskandar Malaysia. Journal of Economics, Business and Management, 3(11), 1031-1036. 
Case, K. E. \& Schiller, R. J. (1990). The efficiency of the market for single-family homes. American Economic Review, 79(1), 125-137.

Case, K. E., Shiller, R. J. \& Quigley, J. M. (2005). Comparing wealth effects: the stock market versus the housing market. Institute of Business and Economic Research Working Papers, No. W01004.

Chen, M. C., Tsai, I. C. \& Chang, C. O. (2007). House prices and household income: do they move apart? Evidence from Taiwan. Habitat International, 31(2), 243-256.

Chow, W. L. \& Shih, Y. C. (1995). Hong Kong housing market: overview, tenure choice, and housing demand. The Journal of Real Estate Finance and Economics, 10(1), 7-21.

Collyns, C. \& Senhadji, A. (2001). Lending booms, real estate bubbles and the Asian Crisis. IMF Working Paper No. 02/20, February 2002.

Dawson, J. W. (2003). Causality in the freedom-growth relationship. European Journal of Political Economy, 19(3), 479-495.

Debrezion, G., Pels, E. \& Rietveld, P. (2006). The impact of rail transport on real estate prices: an empirical analysis of the Dutch housing market. Tinbergen Institute Discussion Paper No.TI 06-031/3.

Department of Statistics. (2015). Number of population, 1970-2040, Malaysia. Available from Population Quick Info Database.

Dowell, D. (1984). The Suburban Squeeze. Berkeley: University of California Press.

Engelhardt, G. V. \& Poterba, J. M. (1991). House prices and demographic change. Journal of Regional Science and Urban Economics, 21(4), 539-546.

Esteban, M. \& Altuzarra, A. (2008). A model of the Spanish housing market. Journal of Post Keynesian Economics, 30(3), 353-373.

Fortin, M. \& Leclerc, A. (2000). Demographic changes and real housing prices in Canada. University of Sherbrooke, Department of Economics, Working Paper No. 00-06.

Geweke, J. (1984). Inference and causality in economic time series models. Handbook of Econometrics, 2, 1101-1144.

Gimeno, R. \& Martinez-Carrascal, C. (2010). The relationship between house prices and house purchase loans: the Spanish case. Journal of Banking and Finance, 34(8), 1849-1855.

Girouard, N. \& Blöndal, S. (2001). House prices and economic activity. OECD Economics Department Working Papers, No 279.

Glaeser, E. (2013). A nation of gamblers: real estate speculation and American history. NBER Working Paper No. 18835.

Gomez, E. T. \& Jomo, K. S. (1997). Malaysia's political economy: politics, patronage and profits. Cambridge: Cambridge University Press.

Goodhart, C. (1995). Price stability and financial fragility. In Sawamoto, K., Nakajima, Z. \& H. Taguchi (Eds.), Financial stability in a changing environment (pp. 439-497). New York: St. Martin's Press.

Goodhart, C. \& Hofmann, B. (2008). House prices, money, credit and the macroeconomy. European Central Bank, Working Paper Series No. 888, April 2008.

Gregory, R. \& Von Winterfeldt, D. (1996). The effects of electromagnetic fields from transmission lines on public fears and property values. Journal of Environmental Management, 48(3), 201-214.

Greiber, C. \& Setzer, R. (2007). Money and housing - evidence for the Euro area and the US. Deutsche Bundesbank Discussion Paper, Series 1: Economic Studies, No. 12/2007.

Guo, M. \& Wu, Q. (2013). The empirical analysis of affecting factors of Shanghai housing prices. International Journal of Business and Social Science, 4(14), 218-223.

Hashim, Z. A. (2010). House price and affordability in housing in Malaysia, Akademika, 78(1), 37-46. 
Hoesli, M. \& Hamelink, F. (1997). An examination of the role of Geneva and Zurich housing in Swiss institutional portfolios. Journal of Property Valuation and Investment, 15(4), 354-371.

Hofmann, B. (2003). Bank lending and property prices: some international evidence. Hong Kong Institute for Monetary Research, Working Paper No. 22/2003.

Huang, H. \& Tang, Y. (2012). Residential land use regulation and the US house price cycle between 2000 and 2009. Journal of Urban Economics, 71(1), 93-99.

Hui, H. C. (2013). Housing price cycles and aggregate business cycles: stylised facts in the case of Malaysia. The Journal of Developing Areas, 47(1), 149-169.

IMF (2000). World economic outlook. Washington, D.C.: IMF.

Johansen, S. (1988). Statistical analysis of cointegration vectors. Journal of Economic Dynamics and Control, 12(2-3), 231-254.

Kakes, J. \& Van Den End, J. W. (2004). Do stock prices affect house prices? Evidence for the Netherlands. Applied Economics Letters, 11(12), 741-744.

Kapopoulos, P. \& Siokis, F. (2005). Stock and real estate prices in Greece: wealth versus credit-price effects. Applied Economics Letters, 12(2), 125-128.

Khazanah Research Institute. (2015). Making housing affordable. Kuala Lumpur: Khazanah Research Institute.

Kiyotaki, N. \& Moore, J. (1997). Credit cycles. Journal of Political Economy, 105(2), 211-248.

Lee, H. A. (2017). Fault lines - and common ground - in Malaysia'a ethnic relations and policies. Yusof Ishak Institute Working Paper No. 63.

Lee, H. G. (2000). Ethnic relations in Peninsular Malaysia: the cultural and economic dimensions. Singapore: Institute of Southeast Asian Studies.

Leung, F., Chow, K. \& Han, G. (2008). Long-term and short-term determinants of property prices in Hong Kong. Hong Kong Monetary Authority Working Paper, No. 15, pp. 1-15.

Levin, E., Montagnoli, A. \& Wright, R. E. (2009). Demographic change and the housing market: evidence from a comparison of Scotland and England. Urban Studies, 46(1), 27-43.

Lim, P. J. (2016). Malaysia's labour market and job creation under the Economic Transformation Program (ETP), 2011 to 2015. Penang: Penang Institute.

Ling, C. S., Almeida, S., Shukri, M. \& Sze, L. L. (2017). Imbalances in the property markets. BNM Quarterly Bulletin, Quarter 3, 26-32.

Liu, H. \& Shen, Y. (2005). Housing prices and general economic conditions: an analysis of Chinese new dwelling market. Tsinghua Science and Technology, 10(3), 334-343.

Lizieri, C. \& Satchell, S. (1997). Interactions between property and equity markets: an investigation of linkages in the United Kingdom 1972-1992. Journal of Real Estate Finance and Economics, $15(1), 11-26$.

Lum, S. K. (2002). Market fundamentals, public policy and private gain: house price dynamics in Singapore. Journal of Property Research, 19(2), 121-143.

Mankiw, N. G. \& Weil, D. N. (1989). The baby boom, the baby bust and the housing market. Regional Science and Urban Economics, 19(2), 235-258.

McQuinn, K. \& O'Reilly, G. (2008). Assessing the role of income and interest rates in determining house prices. Journal of Economic Modeling, 25(3), 377-390.

Meen, G. (2002). The time series behavior of house prices: a transatlantic divide? Journal of Housing Economics, 11(1), 1-23.

Minsky, H. (1982). Can "It" Happen Again? Essays on Instability and Finance. New York: M.E. Sharpe.

Mulder, C. H. (2006). Population and housing: a two-sided relationship. Demographic Research, 15, 401-412.

National Economic Advisory Council. (2010). New economic model for Malaysia, Part I. Putrajaya: National Economic Advisory Council. 
National Property Information Centre/NAPIC. (2014). Annual property market report 2014. Available at http://napic.jpph.gov.my/portal/web/guest/publication

Nellis, J. G. \& Longbottom, J. A. (1981). An empirical analysis of the determination of house prices in the United Kingdom. Urban Studies, 18(1), 9-21.

$\mathrm{Ng}$, A. (2017). Increasing labour income share in Malaysia. How, why and is it good? Presentation at the Fifth Annual Bank Negara Malaysia Economics Research Workshop, 20 November 2017.

Oikarinen. (2010). Foreign ownership of stocks and long-run interdependence between national housing and stock markets - evidence from Finnish data. Journal of Real Estate Finance and Economics, 41(4), 486-509.

Ong, T. S. (2013). Factors affecting the price of housing in Malaysia. Journal of Emerging Issues in Economics, Finance and Banking, 1(5), 414-429.

Peek, J. \& Wilcox, J. A. (1991). The measurement and determinants of single-family house prices. Journal of the American Real Estate \& Urban Economics Association, 19(3), 353-382.

Piergallini, A. (2018). Demographic change and real house prices: a macroeconomic perspective. Unpublished Manuscript. Available at www.economia.uniroma2.it/public/ piergallini/file/Piergallini-2018(1).pdf

Pitkin, J. \& Myers, D. (1994). The specification of demographic effects on housing demand: avoiding the age-cohort fallacy. Journal of Housing Economics, 3(3), 240-250.

Poterba, J. M. (1991). Housing price dynamics: the role of tax policy and demography. Brookings Papers on Economic Activity, 2, 143-148.

Poudyal, N. C., Hodges D. C. \& Merrett, C. D. (2009). A hedonic analysis of the demand for and benefits of urban recreation parks. Land Use Policy, 26(4), 975-983.

Pour, M. S., Khani, P. N., Zamanian, G. \& Barghandan, K. (2013). Specifying the effective determinants of house price volatilities in Iran. Economic Review: Journal of Economics \& Business, 11(2), 15-20.

Quan, D. C. \& Titman, S. (1999). Do real estate prices and stock prices move together? An international analysis. Real Estate Economics, 27(2), 183-207.

Quigley, J M. (1999). Real estate prices and economic cycles. International Real Estate Review, 2(1), $1-20$.

Rasiah, R., Crinis, V. \& Lee, H.-A. (2015). Industrialization and labour in Malaysia. Journal of the Asia Pacific Economy, 20(1), 77-99.

Reinsel, G. C. \& Ahn, S. K. (1992). Vector autoregressive models with unit roots and reduced rank structure: estimation, likelihood ratio test, and forecasting. Journal of Time Series Analysis, 13(4), 353-375.

Roslan, A.H. (2002). Income inequality, poverty and development policy in Malaysia. University Monesquieu - Bordeaux, Group d'Economie du Developpement Working Paper.

Sarip, A. G. \& Lee, Y. F. (2015). Exploring the perception of lifestyle housing development in Malaysia. The Asia Pacific Network for Housing Research, April, pp. 1-11.

Shafii, Z., Abiddin, N. Z. \& Ahmad, A. R. (2009). Ethnic heterogeneity in the Malaysian economy: a special reference to the ethnic group participation in financial planning activities. The Journal of International Social Research, 2 (8), pp. 394-401.

Sutton, G. (2002). Explaining changes in house prices. BIS Quarterly Review, September, 46-55.

Takala, K. \& Pere, P. (1991). Testing the cointegration of house and stock prices in Finland. Finnish Economic Papers, 4(1), 33-51.

Tan, T. H. (2010). Base lending rate and housing prices: their impacts on residential housing activities in Malaysia. Journal of Global Business and Economics, 1(1), 1-14.

Thornton, M. (2009). The economics of housing bubbles. In Powell, B. \& R. Holcombe (Eds), America's housing crisis: a case of government failure. Edison, NJ: Transaction. 
Tsai, I. C. \& Peng, C. W. (2011). Bubbles in the Taiwan housing market: the determinants and effects. Habitat International, 35(2), 379-390.

Tse, R. Y., Ho, C. W. \& Ganesan, S. (1999). Matching housing supply and demand: an empirical study of Hong Kong's market. Construction Management \& Economics, 17(5), 625-633.

Xu, L. \& Tang, B. (2014). On the determinants of UK house prices. International Journal of Economics and Research, 5(2), 57-64.

Wang, Z. \& Zhang, Q. (2014). Fundamental factors in the housing markets of China. Journal of Housing Economics, 25(3), 53-61.

Yeoh, S-P. \& Hirschman, C. (1980). Urbanization and urban growth during colonial rule and independence in peninsular Malaysia. Review of Indonesia and Malayan Affairs, 14(1), 1-22.

Zandi, G., Mahadevan, A., Supramaniam, L., Aslam, A. \& Theng, L. K. (2015). The economic factors affecting residential property price: the case of Penang Island. International Journal of Economics and Finance, 7(12), 200-210. 